\title{
Association of MTHFR polymorphisms and chromosomal abnormalities in leukemia
}

\author{
Thivaratana Sinthuwiwat ${ }^{\mathrm{a}}$, Phanasit Poowasanpetch ${ }^{\mathrm{a}}$, Angsana Wongngamrungroj ${ }^{\mathrm{a}}$, \\ Kamonwan Soonklang ${ }^{\mathrm{b}}$, Somying Promso ${ }^{\mathrm{c}}$, Chirayu Auewarakul ${ }^{\mathrm{d}}$ and Chintana Tocharoentanaphol ${ }^{\mathrm{a}, *}$ \\ ${ }^{a}$ Cancer Cytogenetic Unit, Chulabhorn Hospital, Vipavadee Rangsit rd., Laksi, Bangkok, Thailand \\ ${ }^{\mathrm{b}}$ Data management unit, Chulabhorn Hospital, Vipavadee Rangsit rd., Laksi, Bangkok, Thailand \\ ${ }^{\mathrm{c}}$ Virology and Molecular Microbiology Unit, Department of Pathology, Ramathibodi Hospital, Mahidol University, \\ Bangkok, Thailand \\ ${ }^{\mathrm{d}}$ Division of Hematology, Department of Medicine, Faculty of Medicine Siriraj Hospital, Mahidol University, \\ Bangkok, Thailand
}

\begin{abstract}
Genetic variation in MTHFR gene might explain the interindividual differences in the reduction of DNA repaired and the increase of chromosome breakage and damage. Nowadays, chromosomal rearrangement is recognized as a major cause of lymphoid malignancies. In addition, the association of MTHFR polymorphisms with aneuploidy was found in several studies, making the MTHFR gene as a good candidate for leukemia etiology. Therefore, in this study, we investigated the common sequence variation, $677 \mathrm{C}>\mathrm{T}$ and $1298 \mathrm{~A}>\mathrm{C}$ in the MTHFR gene of 350 fixed cell specimens archived after chromosome analysis. The distribution of the MTHFR polymorphisms frequency was compared in leukemic patients with structural chromosome abnormality and chromosome aneuploidy, as well as in those with no evidence of chromosome abnormalities. We observed a significant decrease in the distribution of $\mathrm{T}$ allele in $677 \mathrm{C}>\mathrm{T}$ polymorphisms among patients with chromosomal abnormalities including both structural aberration and aneuploidy. The same significance result also found in patients with structural aberration when compare with the normal karyotype patients. Suggesting that polymorphism in the MTHFR gene was involved in chromosome abnormalities of leukemia. However, further investigation on the correlation with the specific types of chromosomal aberrations is needed.
\end{abstract}

Keywords: MTHFR, aneuploidy, structural aberrations, polymorphism

\section{Introduction}

MTHFR acts as a critical metabolic process in the regulation of folate and homocysteine levels. Folic acid is essential for the nucleotide precursors in normal DNA synthesis and DNA methylation reactions. A decrease in MTHFR activity results in cellular global hypomethylation and causes altereration in chromosomal recombination and abnormal chromosome segregration [1]. The $2.2 \mathrm{~kb}$ MTHFR gene located on the short arm of chromosome 1 at band 1 p36.3 consists of 11 exons. The two common SNPs found in gene

* Correspondence: Dr. Chintana Tocharoentanaphol, Chulabhorn Cancer Centre, Chulabhorn Hospital, Vipavadee Rangsit rd., Laksi, Bangkok, 10120, Thailand. Tel.: +664 6371452; Fax: +662 5766380; E-mail: chintaphol@hotmail.com. coding area of MTHFR, 677C $>\mathrm{T}$ and $1298 \mathrm{~A}>\mathrm{C}$ are intensively investigated [2]. The substitution of $\mathrm{C}$ for $\mathrm{T}$ at position 677 in exon 4 causes the substitution of alanine for valine in the MTHFR protein. The changing of amino acid lies at the binding site of the cofactor flavin-adinine dinucleotide .The different enzyme activity of MTHFR is reduced to $70 \%$ in homozygous $\mathrm{T} / \mathrm{T}$ and $35 \%$ in heterozygous $\mathrm{C} / \mathrm{T}$ [3]. These differences can affect the genomic instability and decrease genomic DNA methylation in condition of low folate. The result of an increasing level of homocysteine and a decreasing level of methionine can be found in individuals with reduced MTHFR enzyme activity and low folate uptake [4]. The substitution of amino acid glutamate for a valine occurring in the 2nd MTHFR gene polymorphism, 1298A $>\mathrm{C}$ in exon 7 , causes a reduction in the enzyme activity [5]. In contrast to the $677 \mathrm{C}>\mathrm{T}$ 
polymorphisms, individuals with homozygous for the $\mathrm{C}$ allele do not have higher serum homocysteine when compared to those with homozygous A allele [4]. It has been found in many studies that common SNPs in the MTHFR gene are involved in chromosomal nondisjunction and linked to an increasing risk of trisomy 21 [6], as well as other chromosomal aneuploidy [7, 8]. A highly significant increase in the proportion of CT heterozygotes and TT mutant homozygotes in the mother of Down Syndrome child is also shown in various studies $[6,9,10]$. James et al. [11] suggested that the changing in the nucleotide of the MTHFR gene causes a decrease of DNA methylation, leading to an increase of meiotic non disjunction. Meanwhile, recurrent chromosomal abnormalities are important factors in the pathogenesis of hematologic malignancies, including both aneuploidy and structural chromosome abnormalities. A large number of chromosome abnormalities are uniquely associated with the morphology and clinical subsets of leukemia, as well as its prognosis [12]. The correlation of MTHFR polymorphisms and chromosome aneuploidy has been shown in several studies, making the MTHFR variants are good candidate genes for the etiology of chromosome abnormalities in leukemia. In this study, we aim to determine the correlation of the $677 \mathrm{C}>\mathrm{T}$ and $1298 \mathrm{~A}>\mathrm{C}$ MTHFR polymorphisms with the presence of cytogenetic abnormalities among Thai adult patients with acute leukemia, ALL and AML.

\section{Materials and methods}

\subsection{Patients}

Three hundred and fifty unrelated Thai individuals with acute leukemia, ALL and AML were included in this study during March 2006-January 2007. The patients were diagnosed as acute leukemia, ALL or AML by using morphologic analysis of bone marrow aspirates. The samples of each individual were collected for routine cytogenetic analysis at our laboratory.

\subsection{Chromosome study}

Cytogenetic examinations were performed on unstimulated 24-hour in vitro culture of heparinized bone marrow specimens. Chromosomes were banded with quinacrine (Q-banding method). The chromosome abnormalities were described according to the nomenclature of ISCN 2009 (International system for human cytogenetics nomenclature). The 20 metaphases were analyzed when possible, and at least 2 well banded metaphases were photographed and karyotyped by using Ikaros software (Metasystem, Germany)

\subsection{DNA preparation}

Total genomic DNA was isolated from 3:1 methanol: acetic acid fixed cells using the Cell and Tissue Kit (Gentra systems, Minnesta,USA). DNA extraction was performed as recommended by the manufacturer. These fixed-cell suspensions were archived after a routine chromosome analysis from a short term bone marrow culture and stored for 1 year at $-20^{\circ} \mathrm{C}$ in the $3: 1$ methanol:acetic acid solution. The study was approved by the Ethics Committee of Chulabhorn Research Institute.

\subsection{Genotyping of MTHFR}

MTHFR polymorphisms were performed by using HRM method on a LightCycler ${ }^{\circledR}$ instrument (Roche Diagnostics, Mannheim Germany) according to Sinthuwiwat et al. [13].

The amplification reaction of both $677 \mathrm{C}>\mathrm{T}$ and $1298 \mathrm{~A}>\mathrm{C}$ was performed under the same condition.

The reaction mixtures were prepared in 96 well plates PCR containing $1 \mu \mathrm{l}$ genomic DNA, $0.5 \mu \mathrm{l}$ of each primer, $10 \mu 1$ 2xconc. LightCycler ${ }^{\circledR} 480$ High Resolution Master mix, $5 \mu \mathrm{l} \mathrm{H} \mathrm{H}_{2} \mathrm{O}$, PCR-graded, $2 \mu \mathrm{l}$ of $2.5 \mathrm{mM} \mathrm{MgCl}_{2}$, 1U/ul Uracil DNA- Glycosylase was processed according to the manufacturer's instruction (Roche Diagnostics). Fluorescence data were visualized using normalization, temperature-shifting, and different plotting [14], then analyzed using the automated grouping functionalities provided by the LightCycler ${ }^{\circledR}$ 480 Gene scanning software.

\subsection{Statistical analysis}

The association of common SNPs of MTHFR gene and risk of chromosomal abnormalities was calculated by using Fisher's exact test of the R-package software version 2.11.1 both in dominant mode and recessive mode. Statistical significance was determined by using OR and 95\% CI. The comparison of the polymorphisms distribution was performed in the followings.

1. Without chromosome abnormality and with chromosome abnormalities

2. Normal karyotype and Structural rearrangements

3. Normal karyotype and Aneuploidy

4. Structural aberrations and Aneuploidy 
Table 1

Frequency of chromosome aneuploidy found in this study

\begin{tabular}{|l|c|c|c|c|c|}
\hline \multicolumn{1}{|c|}{$\begin{array}{c}\text { Patients } \\
\text { abnormality }\end{array}$} & Male & Female & $\begin{array}{c}\text { Acute } \\
\text { leukemia }\end{array}$ & AML & ALL \\
\hline-7 & 3 & 2 & 2 & 2 & 1 \\
\hline+8 & 7 & 6 & 6 & 4 & 0 \\
\hline+11 & 2 & 1 & 3 & 1 & 3 \\
\hline+21 & 4 & 5 & $5 *$ & 2 & 4 \\
\hline Sex chromosome & 3 & 0 & 0 & 2 & 0 \\
\hline Hyperdiploid & 4 & 7 & 5 & 2 & 0 \\
\hline Others & 4 & 2 & 4 & & 2 \\
\hline
\end{tabular}

* One of the female patients was Down syndrome.

Table 2

Frequency of structural chromosome abnormality found in this study

\begin{tabular}{|l|c|c|c|c|c|}
\hline $\begin{array}{l}\text { Patients } \\
\text { Chromosome }\end{array}$ & Male & Female & $\begin{array}{c}\text { Acute } \\
\text { leukemia }\end{array}$ & AML & ALL \\
\hline $\mathrm{t}(9 ; 22)$ & 9 & 1 & 3 & 3 & 0 \\
\hline $\mathrm{t}(8 ; 21)$ & 13 & 5 & 10 & 8 & 0 \\
\hline $\mathrm{t}(15 ; 17)$ & 5 & 4 & 0 & 9 & 0 \\
\hline $\begin{array}{l}\text { Inversion(16) } \\
\text { Deletion }\end{array}$ & 6 & 1 & 0 & 7 & 5 \\
\hline $\begin{array}{l}\text { Complex } \\
\text { karyotype }\end{array}$ & 17 & 18 & 14 & 13 & 6 \\
\hline other & 7 & 17 & 7 & 11 & \\
\hline
\end{tabular}

\section{Results}

Cytogenetic analysis was conducted in all 350 patients (176 females, 174 males; mean age $40.22 \pm$ 23.66) who were diagnosed as acute leukemia (127 cases), ALL (90 cases) and AML (133 cases). There were 65 males (mean age $44.6 \pm 24.31$ ) and 62 females (mean age $47.21 \pm 20.66$ ) in the acute leukemia cases, followed by 49 males (mean age $20.56 \pm 21.46$ ) and 41 females (mean age $23.58 \pm 22.95)$ in the ALL cases, and 60 males (mean age $47.96 \pm 20.15$ ) and 73 females (mean age $45.22 \pm 19.05$ ) in the AML cases. Of these, 81 patients were age under 15 years old, including 19 acute leukemia (14 males and 5 females; mean age 7.12 \pm 4.61 ), 10 AML (6 males and 4 females; mean age $9.88 \pm 4.76$ ), and 52 ALL ( 29 males and 23 females; mean age $7.14 \pm 4.76$ ). Moreover, of these patients, 163 (46\%) had chromosome abnormalities (notably, $\mathrm{t}(9: 22), \mathrm{t}(8 ; 21)$ and complex karyotype) (Tables 1,2$)$. The genotype analysis of the two common SNPs in MTHFR gene $(677 \mathrm{C}>\mathrm{T}$ and $1298 \mathrm{~A}>\mathrm{C})$ was also successfully performed in all 350 patients. The chromosome abnormalities in each patient were classified as chromosomal aneuploidy or structural aberrations. The patients with only one or more extra or missing chromosomes were grouped as aneuploidy, while those with rearrangement of the structure of chromosome with or without changing in the chromosome number were 


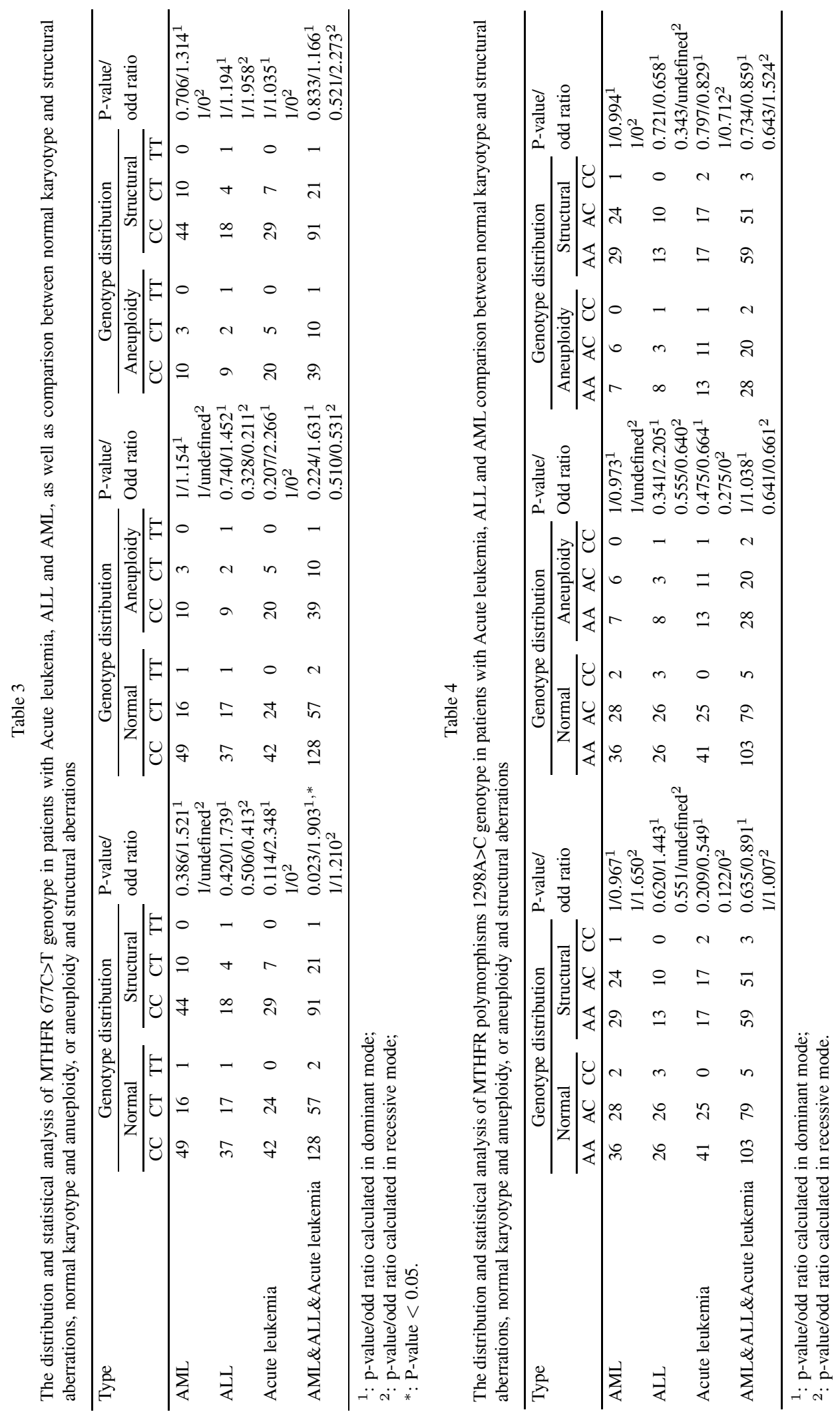


Table 5

The distribution of 677C $>\mathrm{T}$ and 1298A $>$ Cgenotype in patients with Acute leukemia, ALL and AML as well as comparison between no evidence of chromosome abnormalities found and chromosome abnormalities either structural abnormalities or aneuploidy

\begin{tabular}{|c|c|c|c|c|c|c|c|c|c|c|c|c|c|c|}
\hline \multirow[t]{3}{*}{ Type } & \multicolumn{6}{|c|}{ Genotype distribution } & \multirow{3}{*}{$\begin{array}{l}\text { P-value/ } \\
\text { odd ratio }\end{array}$} & \multicolumn{6}{|c|}{ Genotype distribution } & \multirow{3}{*}{$\begin{array}{l}\text { P-value/ } \\
\text { Odd ratio }\end{array}$} \\
\hline & \multicolumn{3}{|c|}{ Normal } & \multicolumn{3}{|c|}{$\begin{array}{l}\text { Structural\& } \\
\text { Aneuploidy }\end{array}$} & & \multicolumn{3}{|c|}{ Normal } & \multicolumn{3}{|c|}{$\begin{array}{l}\text { Structural\& } \\
\text { Aneuploidy }\end{array}$} & \\
\hline & $\mathrm{CC}$ & $\mathrm{CT}$ & TT & $\mathrm{CC}$ & $\mathrm{CT}$ & $\overline{\mathrm{TT}}$ & & $\mathrm{AA}$ & $\mathrm{AC}$ & $\mathrm{CC}$ & $\mathrm{AA}$ & $\mathrm{AC}$ & $\mathrm{CC}$ & \\
\hline AML & 49 & 16 & 1 & 54 & 13 & 0 & $\begin{array}{l}0.413 / 1.437^{1} \\
0.496 / \text { undefined }^{2}\end{array}$ & 36 & 28 & 2 & 36 & 30 & 1 & $\begin{array}{l}1 / 0.968^{1} \\
0.619 / 2.052^{2}\end{array}$ \\
\hline ALL & 37 & 17 & 1 & 27 & 6 & 2 & $\begin{array}{l}0.350 / 1.633^{1} \\
0.558 / 0.310^{2}\end{array}$ & 26 & 26 & 3 & 21 & 13 & 1 & $\begin{array}{l}0.283 / 1.663^{1} \\
1 / 1.948^{2}\end{array}$ \\
\hline Acute leukemia & 42 & 24 & 0 & 49 & 12 & 0 & $\begin{array}{l}0.049 / 2.318^{1} \\
1 / 0^{2}\end{array}$ & 41 & 25 & 0 & 30 & 28 & 3 & $\begin{array}{l}0.156 / 0.593^{1} \\
0.108 / 0^{2}\end{array}$ \\
\hline AML\&ALL\&Acute leukemia & 128 & 57 & 2 & 130 & 31 & 2 & $\begin{array}{l}0.021 / 1.813^{1, *} \\
1 / 0.871^{2}\end{array}$ & 103 & 79 & 5 & 87 & 71 & 5 & $\begin{array}{l}0.830 / 0.934^{1} \\
1 / 0.868^{2}\end{array}$ \\
\hline
\end{tabular}

1: p-value/odd ratio calculated in dominant mode;

$2: \mathrm{p}$-value/odd ratio calculated in recessive mode;

*: P-value $<0.05$.

classified as structural aberrations. The summary of the MTHFR $677 \mathrm{C}>\mathrm{T}$ and $1298 \mathrm{~A}>\mathrm{C}$ genotypes in the 350 leukemic patients was shown in Tables 3 and 4 . The genotype distribution of $677 \mathrm{C}>\mathrm{T}$ polymorphisms was consistent with the Hardy-Weinberg equilibrium. The Allele frequency of $677 \mathrm{C}, 677 \mathrm{~T}, 1298 \mathrm{~A}$ and $1298 \mathrm{C}$ in Thai population was $0.88,0.12,0.73$ and 0.27 respectively [15]. The presence of homozygous 677TT allele was found in $1.22 \%$ of leukemic patients with all forms of abnormal karyotypes and $1.06 \%$ of those with normal karyotypes. There was statistical significance in the distribution of the $677 \mathrm{C}>\mathrm{T}$ genotype among the patients with no evidence of chromosome abnormalities and with abnormal chromosome in a dominant mode $(\mathrm{CT}+\mathrm{TT}$ versus $\mathrm{CC}, P=0.02$ odd ratio $=1.81)$ (Table 5). The frequency of $\mathrm{T}$ allele in the patients with normal karyotype was greater than those with abnormal chromosome ( $p=0.02$, odd ratio 1.61). The same result was found when compared between the patients with structural aberration and patients with normal chromosome $(P=0.02$, odd ratio $=1.9)$. However, there was no significant difference in the 1298A $>C$ genotype either in a dominant mode or in a recessive mode. When considering the presence of both simultaneously 677TT and $1298 \mathrm{CC}$, no statistical difference was found. There was no significant difference of both $677 \mathrm{C}>\mathrm{T}$ and $1298 \mathrm{~A}>\mathrm{C}$ frequency in the comparison between the structural aberration and aneuploidy aberration, or the normal chromosome and the aneuploidy (Table 5).

However, negative association was also found in the geneotype of $677 \mathrm{C}>\mathrm{T}$ and $1298 \mathrm{~A}>\mathrm{C}$ distribution between AML patients with normal karyotype and all abnormal karyotypes. None of the haplotypes was observed more frequently in the comparison between the aneuploidy AML and the normal karyotype AML, the structural aberration AML and the normal karyotype AML, or the aneuploidy AML and the structural aberration AML. The statistical analysis was also similarly performed in ALL and acute leukemia patients. All of the results showed no significant difference in any haplotypes. Like in the individual SNPs, no statistical difference was found when considering the presence of both genotype of $677 \mathrm{C}>\mathrm{T}$ and $1298 \mathrm{~A}>\mathrm{C}$ simultaneously.

\section{Discussion}

Recently, several studies have investigated the relationship between the role of MTHFR polymorphisms and the risk of chromosomal aneuploidy, especially in the Down syndrome. In most studies, the high frequency of Down syndrome child with TT geneotype was found $[6,7,16]$. MTHFR polymorphisms were also reported as a risk factor of leukemia in many studies [2, 17]. The chromosome abnormalities were one of the important events often seen in leukemic patients and also the major cause of leukemia. Therefore, in this study we evaluated the correlation between the MTHFR polymorphisms and the chromosomal abnormalities in our Thai leukemic patients. We found the association between the MTHFR genotype and chromosome abnormalities. The patients who had normal chromosome were more frequently found with $\mathrm{T}$ allele when compared with those who had abnormal chromosome. Nevertheless, our result was not concordant with previous studies [18]. Gallegos-Arreola M.P. found that the TT genotype was found most frequently in the group with chromosome abnormalities. This study reported 
statistically in an opposite direction to what has been observed in our study. The observation of the association of MTHFR and trisomy 21 was also controversially found. Many studies found the correlation between MTHFR and trisomy 21, whereas others showed the conflicting results [19]. It was suggested that the effect of polymorphisms at $677 \mathrm{C}>\mathrm{T}$ might be restricted to certain chromosomes, including chromosome 21 [7].

Chromosome abnormality was believed to be the major cause of leukemia. Therefore, the TT allele causing the reduction of chromosome abnormality should be a protective factor for leukemia. Many studies involving risk factor of leukemia are interested in MTHFR polymorphisms. There were also many conflicts on the results of these studies. The protective effect of the MTHFR 677 homozygous (TT) genotype was observed by Franco et al. [20]. While a German study by Schnakenberg et al. [21] observed no association between pediatric ALL and MTHFR polymorphisms. Pereira et al. [22], conducted a meta-analysis in 13 published case control studies. They observed that individuals with homozygous for MTHFR 677 (TT) failed to show a reduced risk of childhood ALL (OR 0.84, 95\% CI 0.69-1.03), whereas the TT genotype was associated with a significant reduction in the risk of adult ALL development. These results were different probably due to several factors, including the ethnic background, gene to gene interaction, gene to environment interaction, and number of patients recluded in the study.

With the exception of MTHFR genotype distribution between chromosome abnormalities and normal karyotype and between structural abnormalities and nonchromosome abnormalities, we observed no association between the MTHFR polymorphisms and any other groups, Further study on these should be carried on with a larger number of patients in each type of abnormalities.

Additionally, the distribution of MTHFR 1298A $>$ C genotypes was not different in any comparisons. This was in accordance with many studies showing no correlation of the MTHFR 1298A $>\mathrm{C}$ with chromosomal abnormality or with risk of leukemia [23]. The main reason was that the impaired function of the enzyme was not significantly enough to affect the pathway of methylation functions. Thus, there was only a minor effect of $1298 \mathrm{~A}>\mathrm{C}$ on the metabolism pathways [24].

There are controversies about the MTHFR variant presented in many studies, which requires more investigation. Hopefully, the understanding of MTHFR genotype and chromosome abnormalities in leukemic patients will lead to a better preventive approach for leukemia.
In summary, no association of the MTHFR 1298A $>C$ polymorphisms was found in this study as a risk of chromosome abnormalities in leukemic patients. In contrast, the $677 \mathrm{C}>\mathrm{T}$ variant could play some roles as the risk of chromosome aberration in leukemic patients.

\section{References}

[1] S. Friso, S.W. Choi, D. Girelli, J.B. Mason, G.G. Dolnikowski, P.J. Bagley, O. Olivieri, P.F. Jacques, I.H. Rosenberg, R. Corrocher and J. Selhub, A common mutation in the 5,10 methylenetetrahydrofolate reductase gene affects genomic DNA methyla-tion through an interaction with folate status, Proc Natl Acad Sci USA 99 (2002), 5606-5611.

[2] M.N. Sadananda Adiga, S. Chandy,N. Ramachandra, L. Appaji, B.S. Aruna Kumari, G. Ramaswamy, H.S. Savithri and L. Krishnamoorthy, Methylenetetrahydrofolate reductase gene polymorphisms and risk of acute lymphoblastic leukemia in children, Indian journal of cancer 47(1) (2010), 40-45.

[3] S.S. Kang, J. Zhou, P.W.K. Wong, J. Kowalisyn and G. Strokaosch, Intermediate homocysteinemia: a thermolabile variant of methylenetetrahydrofolate reductase, Am J Hum Genet 43 (1988), 414-421.

[4] A.C. Pereira, I.T. Schettert, A.A. Morandini Filho, E.M. Guerra-Shinohara and J.E. Krieger, Methylenetetrahydrofolate reductase (MTHFR) C677T gene variant modulates the homocysteine folate correlation in a mild folate-deficient population, Clin Chim Acta 340 (2004), 99-105.

[5] I. Weisberg, P. Tran, B. Christensen, S. Sibani and R. Rozen, A second genetic polymorphism in methylenetetrahydrofolate reductase (MTHFR) associated with decreased enzyme activity, Mol Genet Metab 64 (1998), 169-172.

[6] C.A. Hobbs, S.L. Sherman, P. Yi, S.E. Hipkins, C.P. Torfs, R.J. Hine, M. Pogribna, R. Rozen and S.J. James, Polymorhpisms in genes involved in folate metabolism as maternal risk factors for Down syndrome, Am J Hum Genet 67 (2000), 623-630.

[7] T.J. Hassold, L.C. Burrage, E.R. Chan, L.M. Judis, S. Schwartz, S.J. James, P.A. Jacobs and N.S. Thomas, Maternal folate polymorphisms and the etiology of human nondisjunction, Am J Hum Genet 9 (2001), 434-439.

[8] K.C. Oliveira , B. Bianco, I.T. Verreschi, A.D. Guedes, B.B. Galera, M.F. Galera, C.P. Barbosa and M.V. Lipay, Prevalence of the polymorphism MTHFR A1298C and not MTHFR C677T is related to chromosomal aneuploidy in Brazilian Turner Syndrome patients, Arq Bras Endocrinol Metabol 52 (2008), 1374-1381.

[9] R. Rubin, Folic acid might reduce risk of Down syndrome, USA Today (1999), sec D1.

[10] N.A. Meguid, A.A. Dardir, M. Khass, L.E. Hossieny, A. Ezzat and M.K. El Awady, MTHFR genetic polymorphism as a risk factor in Egyptian mothers with Down syndrome children, Dis Markers 24 (2008), 19-26.

[11] S.J. James, M. Pogribna, I.P. Pogribny, S. Melnyk, R.J. Hine, J.B. Gibson, P. Yi, D.L. Tafoya, D.H. Swenson, V.L. Wilson and D.W. Gaylor, Abnormal folate metabolism and mutation in the methylenetetrahydrofolate reductase gene may be maternal risk factors for Down syndrome, Am J Clin Nutr 70 (1999), 495-501.

[12] J.D. Rowley, Chromosome abnormalities in Human leukemia, Annu Rev Genet 14 (1980), 17-39. 
[13] T. Sinthuwiwat, P. Poowasanpetch, A. Wongngamrungroj, S. Promso, C. Auewarakul, S. Mooney and C. Tocharoentanaphol, High resolution melting curve analysis for genotyping of common SNP in MTHFR gene using fixed-cell suspension, Mol Cell Probes 22 (2008), 329-332.

[14] M .Hoffmann, J. Hurlebausand C. Weike, Novel method for high-performance melting curve analysis using the LightCycler ${ }^{\circledR} 480$ system, BIOCHEMICA 1 (2007), 17-19.

[15] V. Shotelersuk, C. Ittiwut, P. Siriwan and A. Angspatt, Maternal 677CT/1298AC genotype of the MTHFR gene as a risk factor for cleft lip, J Med Genet $\mathbf{e 6 4}$ (2003), 40.

[16] A.P. Brandalize, E. Bandinelli, P.A. dos Santos, I. Roisenberg and L. Schüler-Faccini, Evaluation of C677T and A1298C polymorphisms of the MTHFR gene as maternal risk factors for Down syndrome and congenital heart defects, Am J Med Genet A 149A (2009), 2080-2087.

[17] K. Robien and C.M. Ulrich, 5, 10-Methylenetetrahydrofolate Reductase Polymorphisms and Leukemia Risk, Am J Epidemiol 157 (2003), 571-582.

[18] M.P. Gallegos-Arreola, L.E. Figuera, J.L. Delgado, A.M. Puebla-Pérez and G.M. Zúñiga-González, The MTHFR polymorphism C677T in adult patients with acute lymphoblastic leukemia is associated with an increased prevalence of cytogenetic abnormalities, Blood Cells Mol Dis 40 (2008), 244-245.

[19] L. Stuppia, V. Gatta, A.R. Gaspari, I. Antonucci, E. Morizio, G. Calabrese and G. Palka, C677T mutation in the 5,10MTHFR gene and risk of Down syndrome in Italy, Eur J Hum
Genet 10 (2002), 388-390.

[20] R.F. Franco, B.P. Simões, L.G. Tone, S.M. Gabellini, M.A. Zago and R.P. Falcão, The methylenetetrahydrofolate reductase $C 677 T$ gene polymorphism decreases the risk of childhood acute lymphocytic leukaemia, Br J Haematol 115 (2001), 616-618.

[21] E. Schnakenberg, A. Mehles, G. Cario, K. Rehe, K. Seidemann, B. Schlegelberger, H.A. Elsner, K.H. Welte, M. Schrappe and M. Stanulla, Polymorphisms of methylenetetrahydrofolate reductase (MTHFR) and susceptibility to pediatric acute lymphoblastic leukemia in German study population, BMC Med Genet 6 (2005), 1-5.

[22] T.V. Pereira, M. Rudnicki , A.C. Pereira , M.S. Pombo-deOliveira and R.F. Franco, 5,10-Methylenetetrahydrofolate reductase polymorphisms and acute lymphoblastic leukemia risk: a meta-analysis, Cancer Epidemiol Biomarkers Prev 15 (2006), 1956-1963.

[23] A.K. Rai, S. Singh, S. Mehta, A. Kumar, L.K. Pandey and R. Raman, MTHFR C677T and A1298C polymorphisms are risk factors for Down's syndrome in Indian mothers, J Hum Genet 51(Epub) (2006), 278-283.

[24] S. Friso, D. Girelli, E. Trabetti, O. Olivieri, P. Guarini, P.F. Pignatti, R. Corrocher and S.W. Choi, The MTHFR 1298A >C polymorphism and genomic DNA methylation in human lymphocytes, Cancer Epidemiol Biomarkers Prev 14 (2005), 938943. 


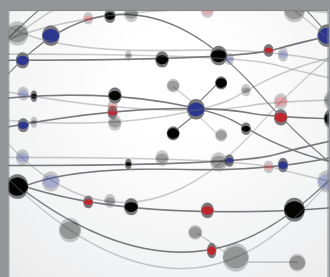

The Scientific World Journal
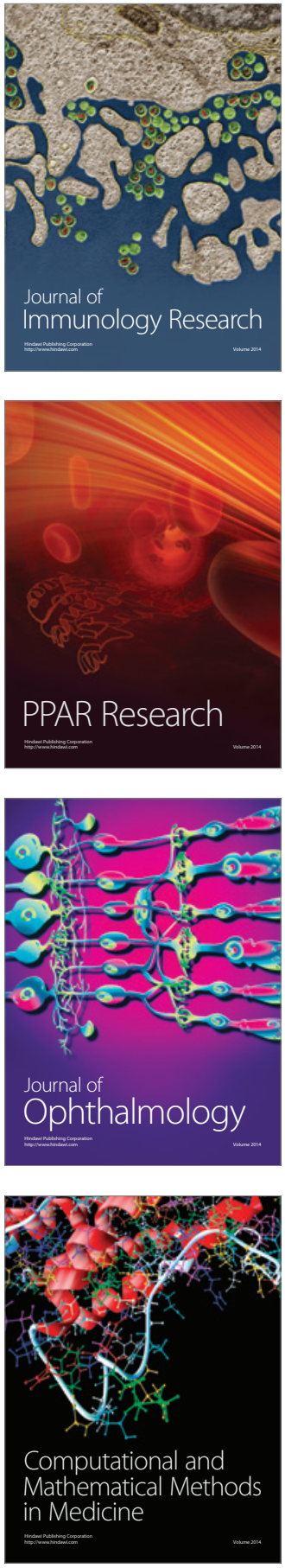

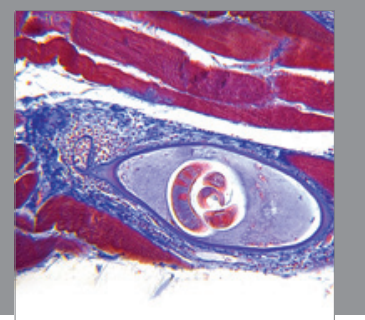

Gastroenterology

Research and Practice
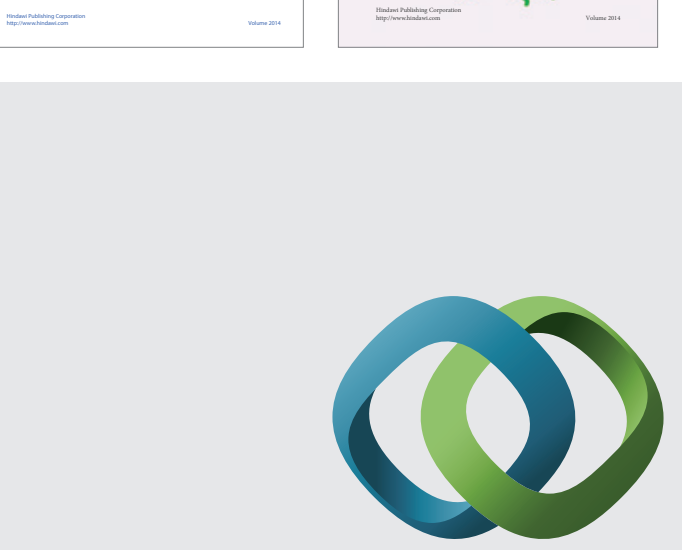

\section{Hindawi}

Submit your manuscripts at

http://www.hindawi.com
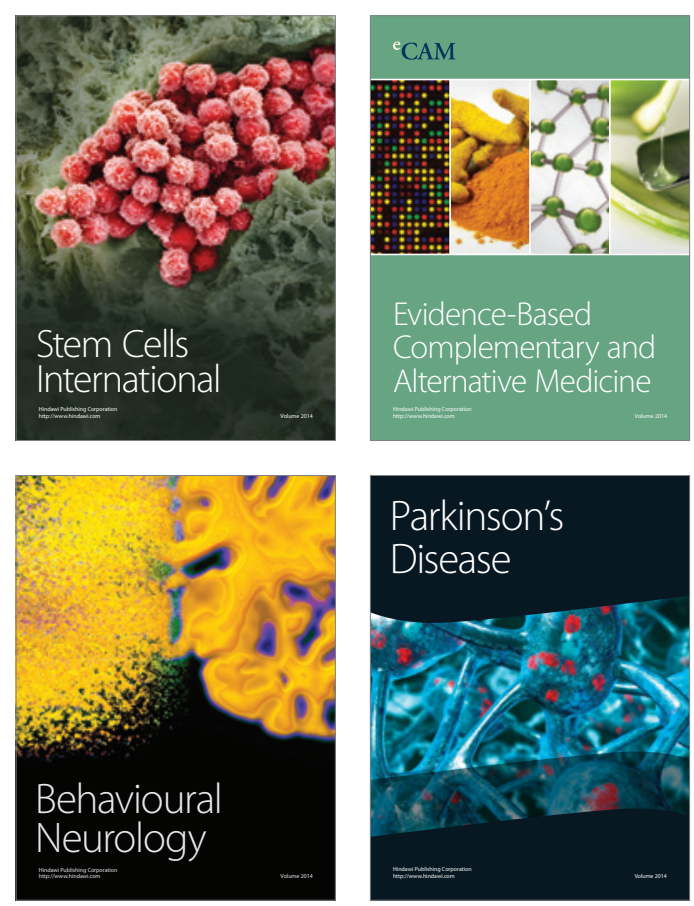

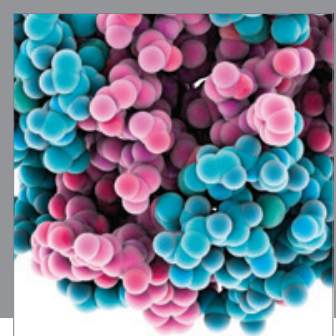

Journal of
Diabetes Research

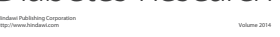

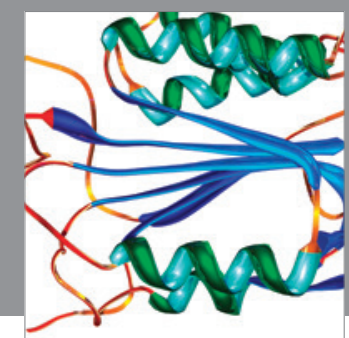

Disease Markers
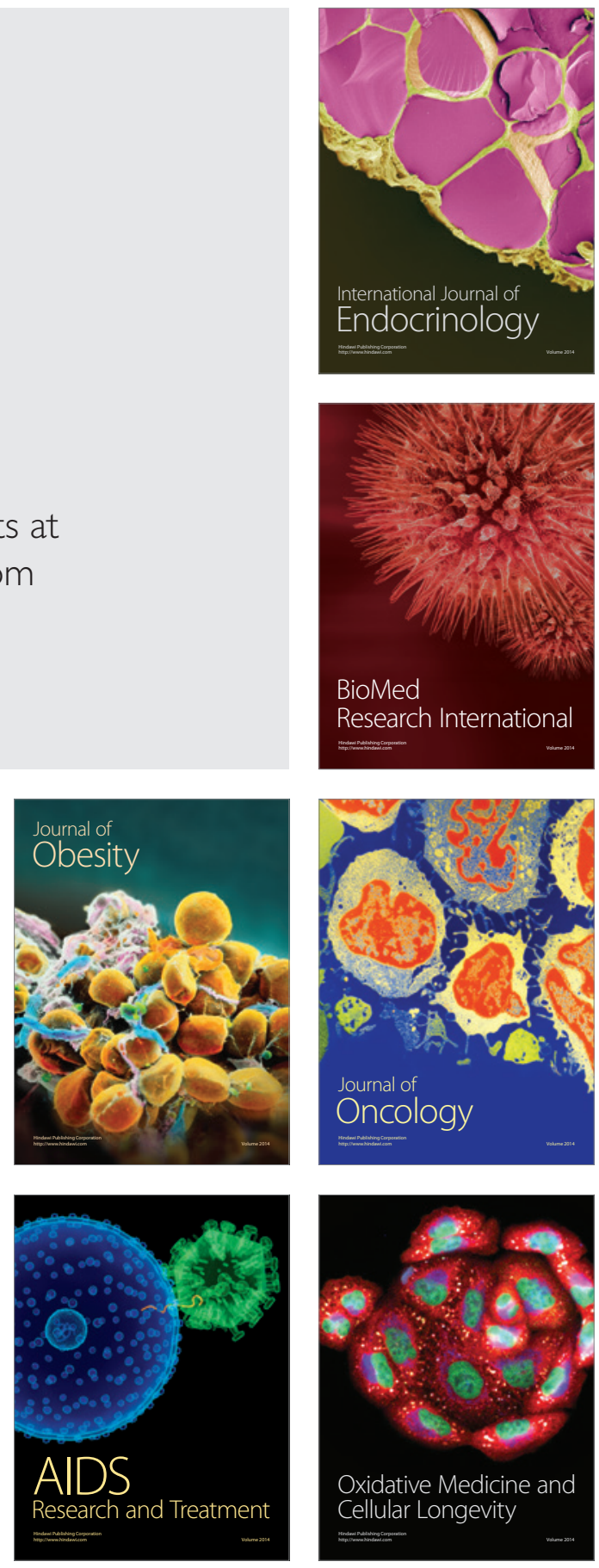